\title{
GRINDING IMIDATION OF ANHYDRIDES ON SMECTITE CLAYS AS RECYCLABLE AND HETEROGENEOUS CATALYSTS UNDER SOLVENT-FREE CONDITIONS
}

\author{
OMID MARVI * \\ ${ }^{1}$ Department of Chemistry, Payam Noor University, PO Box 19395-3697 Tehran, Iran
}

\begin{abstract}
Imidation of various anhydrides employing solvent-free grindstone technique using smectite clays as recyclable and green catalysts was examined and obtained excellent yields.
\end{abstract}

Key words: Smectite clays, Grindstone technique, Solvent-free, Imidation

\section{INTRODUCTION}

Cyclic imides ${ }^{1}$ play an important role in organic syntheses and in medicinal chemistry. For instance, cyclic imides, particularly phthalimides, have been widely used as amino acid protection groups ${ }^{2}$ and have attracted considerable attention in medicinal chemistry ${ }^{3}$. Maleimides are important constituents of peptide-conjugate haptens, antibody-antibody conjugates, immune conjugates, and enzyme inhibitors ${ }^{4}$.

Classically, imides are prepared by the reaction of amides with acyl chlorides, anhydrides, and carboxylic esters or acids ${ }^{5}$. In addition, other reported methods include the reaction of azlactones with $\mathrm{O}_{2}$ and $\mathrm{Pd} / \mathrm{C}{ }^{6}$, aminocarbonylation of aryl bromides ${ }^{7}$, reaction of pentafluorophenyl (PFP) esters with deprotonated amides ${ }^{8}$, couplings of amides with thioesters using $\mathrm{FeCl}_{2} / \mathrm{NBS}^{9}$, amidation of an aldehyde with $\mathrm{CuBr} / \mathrm{NBS}{ }^{10}$, and oxidation of $N$-alkylamides ${ }^{11}$.

Most of the above reported methods have one or more of the following drawbacks: high temperature, long reaction time, use of a solvent or two phase systems, toxic reagents, corrosive and hazardous oxidants, tedious work-up, and side reactions such as elimination to nitriles, formation of triacyl amides, or acyl group transfer. On the other hand, even though imidation reaction is the oldest and uses the known reaction method, it continues to attract the attention of chemists due to its interesting synthetic and mechanistic challenges.

Natural alumosilicates, such as zeolites and clays, are solid acids that could act as an efficient alternative to liquid acids. Natural and modified clays have attracted attention due to their extremely versatile properties and high potential in green chemistry ${ }^{12-15}$. Many clay based catalysts such as K-10 and KSF montmorillonites, hectorite, bentonite, kaolin, envirocat, etc. are commercially available and two most common clays applied in organic synthesis are K-10 and KSF clays. Though the physicochemical properties of the clays are similar their BET surface areas differ.

In continuation of ongoing investigations exploring the use of montmorillonites as solid supports in the synthesis and reactivity of organic compounds ${ }^{16}$, this paper reports a simple, efficient, inexpensive and solvent free procedure for the $N$-unsubstituted imidation of different cyclic anhydrides using smectite clays as efficient heterogeneous and recyclable catalysts employing grindstone technique (Scheme 1). The solid clays can be recovered later and reused in the subsequent reactions. Details of recyclability of the recovered solid clays have been shown in the Table 1 .<smiles>O=C1CCC(=O)O1</smiles>

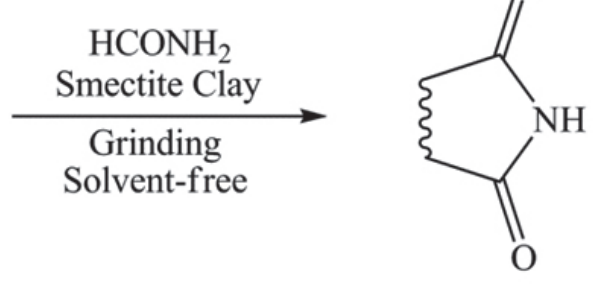

Scheme 1. Solvent-free grinding synthesis of $N$-unsubstituted cyclic imides on clays.

Table 1. The yields and reaction times for clay supported solvent-free grinding synthesis of $N$-unsubstituted cyclic imides.

\begin{tabular}{|c|c|c|c|c|}
\hline Entry & Imide & $\begin{array}{l}\frac{\text { Yield }^{\mathrm{a}}, \%}{\text { KSF/ Bentonite }} \\
\text { Hectorite/ K10 }\end{array}$ & $\begin{array}{l}\frac{\text { Time, } \min }{\text { KSF/ Bentonite }} \\
\text { Hectorite/ K10 }\end{array}$ & 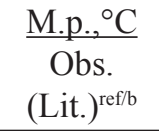 \\
\hline \multirow{2}{*}{1} & & $92(89) / 94(90)$ & $10 / 15$ & $231-234$ \\
\hline & & $91(88) / 90(89)$ & $20 / 20$ & $(232-235)^{b}$ \\
\hline \multirow[t]{2}{*}{2} & & $91(87) / 95(91)$ & $10 / 20$ & $216-218$ \\
\hline & & $92(89) / 93(90)$ & $15 / 15$ & $(213-215)^{\mathrm{b}}$ \\
\hline
\end{tabular}


3

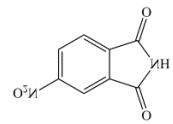

4<smiles>CC1CC(C)CC2C(C)CC(C)C2C1</smiles>

5

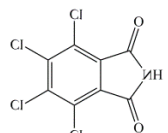

6<smiles>CC1CC2CC3C(C)C(C)C(C)C3C1C(C)C2C</smiles>

7

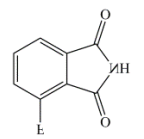

8<smiles>CC1CC2CCC1C1CC(I)CCC21</smiles>

9

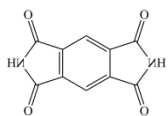

10<smiles>CC1CCC2CCCC2C1</smiles>

11<smiles>CC(C)C1CCCC1</smiles>

12<smiles>CC1CC2CC3CCC(C4CCC5CC4C(C)C5C)CC3C1C2</smiles>

13

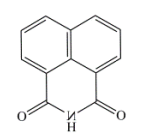

14
93(90)/95(91)

89(86)/93(89)

94(89)/95(93)

90(89)/93(89)

95(89)/97(93)

92(89)/93(89)

91(85)/94(89)

$90(87) / 90(88)$

93(90)/95(91)

90(88)/92(89)

92(88)/93(91)

90(85)/92(89)

93(88)/94(90)

91(89)/92(89)

92(89)/95(92)

$89(85) / 90(88)$

91(88)/93(89)

$89(85) / 91(87)$

93(88)/95(91)

88(85)/91(86)

90(85)/93(87)

$89(85) / 87(83)$

93(91)/94(88)

$89(84) / 90(84)$
$10 / 15$

$15 / 20$

20/15

$15 / 20$

$10 / 15$

20/15

$15 / 20$

$25 / 20$

$15 / 20$

20/15

$15 / 25$

20/15

$20 / 20$

$20 / 25$

$20 / 25$

$30 / 30$

20/30

$25 / 30$

20/30

$30 / 25$

$30 / 20$

$30 / 25$

$25 / 20$

$30 / 25$
197-199

$(195-199)^{b}$

217-221

$(218-220)^{19 a}$

338-341

$(341-343)^{19 a}$

$>340$

$(>300)^{\mathrm{b}}$

177-182

$(179-182)^{19 b}$

172-176

$(174-176)^{19 b}$

$>370$

$(>410)^{19 \mathrm{a}}$

124-126

$(125-127)^{b}$

90-94

$(91-93)^{\mathrm{b}}$

$>380$

$(>410)^{19 a}$

304-308

$(300-302)^{19 a}$

$>370$

$(>410)^{19 a}$

${ }^{a}$ Isolated yields. The yields indicated in the parenthesis correspond to those reactions which the recovered clays were used. The fresh solid clay portion applied in the first step was filtered off at the end of reaction, washed with methanol $(2 \times 30 \mathrm{~mL})$ and dried at $120^{\circ} \mathrm{C}$ under the reduced pressure to be reused in the subsequent reaction. After three successive runs, recycled smectite clays showed no loss of efficiency with regard to reaction time and yield.

${ }^{\mathrm{b}}$ Melting point of a commercial sample. 


\section{RESULTS AND DISCUSSION}

The clay supported grinding synthesis of $N$-unsubstituted cyclic imides were through the reaction of anhydrides with formamide (Scheme 1) under solvent-free conditions. Results summarized in the Table 1 indicate the scope and generality of the reaction with respect to the various anhydrides. The nature of the substituents on the aromatic ring of anhydrides has different influences. The presence of the electron withdrawing groups such as nitro and fluorine give high yields of products compared to phthalic anhydride (entries 2-5, 7 and 8).

The catalysts studied were smectite-type laminar silicates. The structure of an elementary sheet of these materials consists of an octahedral layer of $\mathrm{Al}\left[\mathrm{O}_{4}(\mathrm{OH})_{2}\right]$ (for montmorillonites $\mathrm{KSF}, \mathrm{K}-10$, and bentonite) or $\mathrm{Mg}\left[\mathrm{O}_{4}(\mathrm{OH})_{2}\right]$ (for hectorite) sandwiched between two tetrahedral layers of $\mathrm{SiO}_{4}$ tetrahedral. The total concentration of acid sites on the catalyst surface was determined by $\mathrm{NH}_{3}$ adsorption ${ }^{17 \mathrm{a}}$ and the surface area by the BET method ${ }^{17 b}$. The key factor for the reaction is the acidity of the clay, while the surface area seems to play a less important role. Indeed, all clays display activity in the reaction, but of all the catalysts examined, the bentonite Bieliaca, which shows the greatest overall acidity, are the most efficient catalyst ${ }^{18}$. Chemical composition, surface area and surface acidity of the applied clays are shown in Table 2 . In this method, the reaction time has been shortened and the synthesis of these compounds has the feature of rapid reaction, convenient operation, high yield, and clean. The use of the solid clay catalyst in this method offers high yields of products compared to conventional procedures. From the other advantages of our method is the recyclability of solid clay. The used clay catalysts in the first cycle were recovered by filtration, washed with methanol and reused. Recyclability details of clays have been explained in the footnote of Table 1. A comparison of efficiency of the present method with some of previous reported methods in literature for the synthesis of imide 1 was shown in Table 3 as well. Slightly higher isolated yield was found in this method compared to the previous reported results.

Table 2. Chemical composition, surface area and surface acidity of applied smectites.

\begin{tabular}{|c|c|c|c|c|c|c|c|c|}
\hline Clay & $\begin{array}{c}\text { surface area } \\
\left(\mathrm{m}^{2} / \mathrm{g}\right)\end{array}$ & $\begin{array}{c}\text { surface acidity } \\
\left(\mathrm{meq} . \mathrm{H}^{+} / \mathrm{g}\right)\end{array}$ & $\begin{array}{c}\mathrm{SiO}_{2} \\
(\%)\end{array}$ & $\begin{array}{c}\mathrm{Al}_{2} \mathrm{O}_{3} \\
(\%)\end{array}$ & $\begin{array}{c}\mathrm{Fe}_{2} \mathrm{O}_{3} \\
(\%)\end{array}$ & $\begin{array}{c}\mathrm{CaO} \\
(\%)\end{array}$ & $\begin{array}{c}\mathrm{MgO} \\
(\%)\end{array}$ & $\begin{array}{c}\mathrm{Na}_{2} \mathrm{O} \\
(\%)\end{array}$ \\
\hline KSF Clay & $15 \pm 10$ & 0.70 & 54.0 & 17.0 & 5.2 & 1.5 & 2.5 & 0.4 \\
\hline K-10 Clay & $200 \pm 10$ & 0.65 & 73.0 & 14.0 & 2.7 & 0.2 & 1.1 & 0.6 \\
\hline Bentonite & $205 \pm 10$ & 0.77 & 70.9 & 20.1 & 0.2 & 1.2 & 2.5 & 0.4 \\
\hline Hectorite & $63 \pm 10$ & 0.21 & 34.7 & 0.7 & $0.3(\mathrm{FeO})$ & 23.4 & 15.3 & 1.3 \\
\hline
\end{tabular}

Table 3. A comparison between synthesis of imide (1) in this method and earlier reported methods.

\begin{tabular}{|c|c|c|c|c|c|}
\hline Reaction & $\begin{array}{c}\text { Temperature/ } \\
\text { power }\end{array}$ & Reaction conditions & Time & $\begin{array}{l}\text { Yield } \\
(\%)\end{array}$ & Ref. \\
\hline Phthalic acid/ ureas/ imidazole & $100\left({ }^{\circ} \mathrm{C}\right)$ & Neat/ Solventless & $3 \mathrm{~h}$ & 25 & $20 \mathrm{a}$ \\
\hline Phthalic acid/ ureas/ imidazole & $150\left({ }^{\circ} \mathrm{C}\right)$ & DMF/reflux & $3 \mathrm{~h}$ & 76 & $20 \mathrm{a}$ \\
\hline Anhydride/ formamide & $650 \mathrm{~W}$ & MW & $3 \min$ & 90 & $19 \mathrm{a}$ \\
\hline Anhydride/ $\mathrm{NH}_{2} \mathrm{OH}(\mathrm{HCl}) /$ DMAP & $150\left({ }^{\circ} \mathrm{C}\right)$ & MW (CEM) & $5 \mathrm{~min}$ & 70 & $20 \mathrm{~b}$ \\
\hline Anhydride/ formamide & $400 \mathrm{~W}$ & MW & $2 \mathrm{~min}$ & 92 & $20 \mathrm{c}$ \\
\hline Anhydride/ formamide/ bentonite & r.t. & Grinding/Solvent-free & $15 \mathrm{~min}$ & 94 & This work \\
\hline
\end{tabular}

The mechanism of this reaction is described as below (Scheme 2). Here, we only emphasize minor differences and advantages that are due to the use of solid catalysis. As this reaction is carried out in a solvent-free, open reaction system, the key step is the adsorption of the carbonyl compound on the surface of the catalyst. The clay is considered to be a mixed Brønsted-Lewis solid acid. The majority of the acid centers are of Lewis acid type. The adsorption occurs when the electron rich carbonyl oxygen interacts with a surface Lewis acid center, and it is of rather chemical than physical nature. This Lewis acid-base interaction anchors the aldehyde and initiates strong electrophilic character on the carbonyl carbon, resulting in a surface-bound intermediate of carbocationic nature.

\section{EXPERIMENTAL}

\section{Materials and measurements}

Chemicals were purchased from Aldrich and Merck chemical companies and used without further purification. Commercially available heterogeneous clays, montmorillonites KSF and K10 (Fluka), hectorite [SHCa-118 (Clay Source)] and bentonite [Bieliaca (Rudex)] were tested in this method.

Melting points were measured on an Electro thermal 9100 apparatus. ${ }^{1} \mathrm{H}$ NMR spectra were recorded by a FTNMR BRUKER DRX 500 Avence spectrometer $(500 \mathrm{MHz})$. Chemical shifts were measured in ppm from TMS. $\mathrm{CDCl}_{3}$ was used as solvent as well as the internal standard. The IR spectra were recorded on a Perkin Elmer FT-IR GX instrument in KBr discs.

\section{General procedure}

A mixture of anhydride $(1 \mathrm{mmol})$, formamide $(1.1 \mathrm{mmol}$ for monoanhydrides and $2.2 \mathrm{mmol}$ for dianhydrides) and $1 \mathrm{~g}$ clay was ground together in a mortar using pestle for the time described in Table 1 . The reaction mixture was warmed. After completing the reaction (monitored by TLC, after observing no anhydride presence in the reaction mixture), the product was extracted by washing clay with chloroform $(2 \times 15 \mathrm{~mL})$, the solvent was removed under vacuum to afford the relevant $N$-unsubstituted cyclic imide. The solid imide was washed thoroughly with water, dried, and then recrystallized from ethanol. The solid clay portion was washed with methanol and dried at $120^{\circ} \mathrm{C}$ under a reduced pressure to be reused in the subsequent reactions which showed the gradual decrease in the activity (Table 1). Isolated products were characterized by melting points, IR, ${ }^{1} \mathrm{H}$ NMR spectrometric data and were compared with the literature or authentic samples.

Phthalimide (1): ${ }^{1} \mathrm{HNMR}\left(500 \mathrm{MHz}, \mathrm{CDCl}_{3}\right): \delta=11.73$ (bs, $\left.1 \mathrm{H}\right), 7.29$ (s, 4H); IR (KBr, cm-1): 3334, 3021, 1748, 1796, 1612, 1375, 1315.

3-Nitrophthalimide (2): ${ }^{1} \mathrm{HNMR}\left(500 \mathrm{MHz}, \mathrm{CDCl}_{3}\right): \delta=11.65(\mathrm{bs}, 1 \mathrm{H})$, $8.12(\mathrm{~m}, 1 \mathrm{H}), 8.02(\mathrm{~m}, 1 \mathrm{H}), 7.95(\mathrm{~m}, 1 \mathrm{H})$; IR $\left(\mathrm{KBr}, \mathrm{cm}^{-1}\right): 3212,3041,1763$, $1701,1626,1542,1357$

4-Nitrophthalimide (3): ${ }^{1} \mathrm{HNMR}\left(500 \mathrm{MHz}, \mathrm{CDCl}_{3}\right): \delta=11.81(\mathrm{bs}, 1 \mathrm{H})$, $8.21(\mathrm{~m}, 1 \mathrm{H}), 8.16(\mathrm{~m}, 1 \mathrm{H}), 8.09(\mathrm{~m}, 1 \mathrm{H})$; IR $\left(\mathrm{KBr}, \mathrm{cm}^{-1}\right): 3292,3071,1757$, $1734,1638,1517,1357$

4,5-Dichlorophthalimide (4): ${ }^{1} \mathrm{HNMR}\left(500 \mathrm{MHz} \mathrm{CDCl}_{3}\right): \delta=11.78$ (bs, 1H), 8.22 (s, 2H); IR (KBr, cm $\left.{ }^{-1}\right): 3263,3041,1761,1725,1675,1315,1301$. 2,3,4,5-Tetrachlorophthalimide (5): ${ }^{1} \mathrm{HNMR}\left(500 \mathrm{MHz}, \mathrm{CDCl}_{3}\right): \delta=$ 
11.85 (bs, 1H); IR (KBr, cm $\left.{ }^{-1}\right): 3235,3052,1745,1772,1708,1355,1314$. 2,3,4,5-Tetrabromophthalimide (6): ${ }^{1} \mathrm{HNMR}\left(500 \mathrm{MHz}, \mathrm{CDCl}_{3}\right): \delta=$ 11.92 (bs, 1H); IR (KBr, cm $\left.{ }^{-1}\right): 3242,3013,1741,1745,1721,1385,1359$. 3-Fluorophthalimide (7): ${ }^{1} \mathrm{HNMR}\left(500 \mathrm{MHz}, \mathrm{CDCl}_{1}\right)$ : $\delta=11.84$ (bs, $\left.1 \mathrm{H}\right)$ $8.21(\mathrm{~m}, 1 \mathrm{H}), 8.17(\mathrm{~m}, 1 \mathrm{H}), 8.02(\mathrm{~m}, 1 \mathrm{H})$; IR $\left(\mathrm{KBr}, \mathrm{cm}^{-1}\right): 3275,3047,1785$ $1712,1616,1327,1048,886$.

4-Fluorophthalimide (8): ${ }^{1} \mathrm{HNMR}\left(500 \mathrm{MHz}, \mathrm{CDCl}_{3}\right)$ : $\delta=11.82(\mathrm{bs}, 1 \mathrm{H})$, $8.28(\mathrm{~m}, 1 \mathrm{H}), 8.14(\mathrm{~m}, 1 \mathrm{H}), 8.11(\mathrm{~m}, 1 \mathrm{H})$; IR $\left(\mathrm{KBr}, \mathrm{cm}^{-1}\right): 3273,3041,1779$, 1711, 1647, 1321, 1071, 874 .

Pyromelliticdiimide (9): ${ }^{1} \mathrm{HNMR}\left(500 \mathrm{MHz}, \mathrm{CDCl}_{3}\right): \delta=11.84$ (bs, $\left.2 \mathrm{H}\right)$ 8.10 (s, 2H); IR (KBr, $\left.\mathrm{cm}^{-1}\right): 3198,3068,1772,1698,1378,1357,1156,1061$, $860,727$.

Succinimide (10): ${ }^{1} \mathrm{HNMR}\left(500 \mathrm{MHz}, \mathrm{CDCl}_{3}\right): \delta=10.28$ (bs, $\left.1 \mathrm{H}\right), 2.83$ $\left(\mathrm{s}, 4 \mathrm{H}, \mathrm{CH}_{2}\right)$; IR $\left(\mathrm{KBr}, \mathrm{cm}^{-1}\right): 3395,3058,2962,2924,1773,1692,1329,1178$, 845 .

Maleimide (11): ${ }^{1} \mathrm{HNMR}\left(500 \mathrm{MHz}, \mathrm{CDCl}_{3}\right): \delta=10.91(\mathrm{bs}, 1 \mathrm{H}), 6.85$ (s, $2 \mathrm{H}$, vinilic); IR (KBr, cm $\left.\mathrm{cm}^{-1}\right): 3375,3203,3069,1779,1715,1146,1078,869$.

3,3',4,4'-Biphenyltetracarboxylicdiimide (12): ${ }^{1} \mathrm{HNMR}(500 \mathrm{MHz}$ $\left.\mathrm{CDCl}_{3}\right): \delta=11.94(\mathrm{bs}, 2 \mathrm{H}), 8.34(\mathrm{~m}, 4 \mathrm{H}), 8.12(\mathrm{~m}, 2 \mathrm{H})$; IR $\left(\mathrm{KBr}, \mathrm{cm}^{-1}\right): 3248$, $1769,1795,1726,1634,1486,1339,1309,1115,1068$.

1,8-Naphthalenedicarboxylicimide (13): ${ }^{1} \mathrm{HNMR}(500 \mathrm{MHz}, \mathrm{CDCl})$ : $\delta=11.89(\mathrm{bs}, 1 \mathrm{H}), 8.59(\mathrm{~m}, 4 \mathrm{H}), 7.89(\mathrm{~m}, 2 \mathrm{H})$; IR $\left(\mathrm{KBr}, \mathrm{cm}^{-1}\right): 3296,3057$, $2817,1711,1658,1361,859$.

1,4,5,8-Naphthalenetetracarboxylicdiimide (14): ${ }^{1} \mathrm{HNMR}(500 \mathrm{MHz}$, $\left.\mathrm{CDCl}_{3}\right): \delta=12.08(\mathrm{bs}, 2 \mathrm{H}), 8.96(\mathrm{~s}, 4 \mathrm{H}) ; \mathrm{IR}\left(\mathrm{KBr}, \mathrm{cm}^{-1}\right): 3286,3014,2893$ $1715,1667,1354,1327,892$.

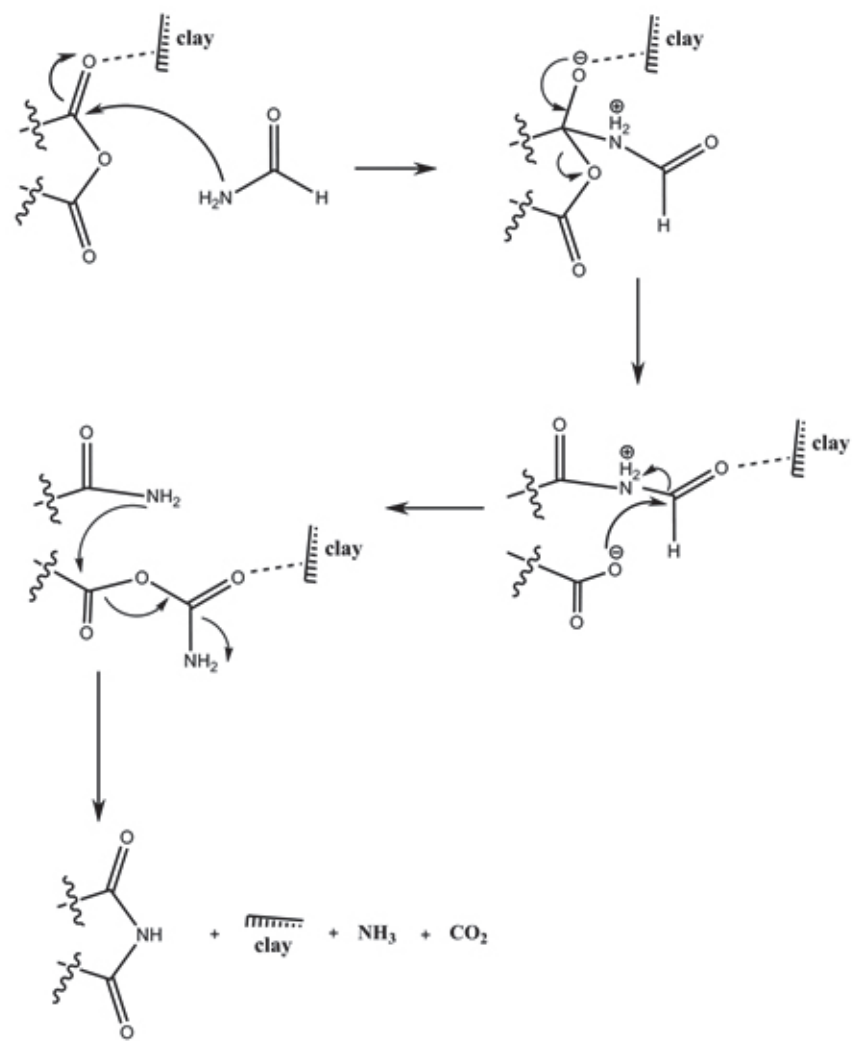

Scheme 2. Possible mechanism for smectite supported grinding solventfree imidation.

\section{CONCLUSION}

In conclusion, a simple and efficient procedure for the synthesis of $\mathrm{N}$-unsubstituted cyclic imides was established. This present method is superior since it is eco-friendly, advantageous over previously described methods in yield, requires no special apparatus, there is simplicity of operation, and is non-hazardous, simple and convenient. In addition, the simple experimenta and product isolation procedures combined with the easy recovery and reuse of these worthwhile natural clays play an important role in development of the clean and environmentally friendly strategy in this new and benign method.

\section{ACKNOWLEDGMENT}

Financial support from the Payam Noor University (PNU), Roodsar, Iran is gratefully appreciated.

\section{REFERENCES}

1. a) S. K. Upadhyay, S. R. K. Pingali , B. S. Jursic, Tetrahedron Lett. 51, 2215, (2010); b) E. Benjamin, Y. Hijji, Molecules, 13, 157, (2008); c) B. Guthrie, Z. Wang, J. Li, Mater. Res. Soc. Symp. Proc., 1091, (2008).

2. a) J. O. Osby, M. G. Martin, B. Ganem, Tetrahedron Lett. 25, 2093 , (1984); b) P. G. M. Wuts, T. W. Greene, Greene's Protective Groups in Organic Synthesis, 4th ed.; Wiley: New York, (2007).

3. a) S. M. Sondhi, R. Rani, P. Roy, S. K. Agrawal, A. K. Saxena, Bioorg. Med. Chem. Lett., 19, 1534, (2009); b) S. G. Stewart, M. E. Polomska, R. W. Lim, Tetrahedron Lett., 48, 2241, (2007)

4. a) K. Kafi, D. J. Betting, R. E. Yamada, M. Bacica, K. K. Steward Timmerman, J. M. Mol. Immunol., 448, (2009); b) S. Karim, C. S. Johansson, J. K. Weltman, Nucleic Acids Res., 23, 2037, (1995); c) R. Wattanadilok, P. Sawangwong, C. Rodrigues, H. Cidade, M. Pinto, E. Pinto, A. Silva, A. Kijjoa, Mar. Drugs, 5, 40, (2007);

5. O. H. Wheeler, O. Rosado, In The Chemistry of Amides, J. Zabicky, Ed., John Wiley and Sons: New York, 335, (1970).

6. R. B. Bates, F. A. Fletcher, K. D. Janda, W. A. Miller, J. Org. Chem., 49, 3038, (1984)

7. A. Schnyder, F., Indolese, J. Org. Chem., 67, 594, (2002).

8. M. B. Andrus, W. Li, R. F. Keyes, Tetrahedron Lett., 39, 5465, (1998).

9. F. Wang, H. Liu, H. Fu, Y. Jiang, Y. Zhao, Adv. Synth. Catal., 351, 246, (2009).

10. L. Wang, H. Fu, Y. Jiang, Y. Zhao, Chem. Eur. J., 14, 10722, (2008),

11. a) L. Xu, S. Zhang, M. L. Trudell, Chem. Commun., 1668, (2004); b) Z Jin, B. Xu, G. B. Hammond, Tetrahedron Lett., 52, 1956, (2011); c) M. M. Khodaei, E. Nazari, Tetrahedron Lett., 53, 2881, (2012).

12. a) T. Cseri, S. Bekassy, F. Figueras, E. Cseke, E., de Menorval, R. Dutartre, Appl. Catal. A, 132, 141, (1995); b) T-K. Huang, R. Wang, L. Shi, X-X. Lu , Catal. Commun., 9, 1143, (2008).

13. a) M. Choudary, N. S. Chowdari, M. L. Kantam, R. Kannan, Tetrahedron Lett., 40, 2859, (1999). b) P. R. Crisostomo, R. Carrillo, T. Martin, V. S. Martin, Tetrahedron Lett., 46, 2829, (2005).

14. a) M. D. Nikalje, P. Phukan, A. Sudalai, Org. Prep. Proceed. Int., 32, 1, (2000); b) T. Kawabata, T. Mizugaki, K. Ebitani, K. Kaneda, Tetrahedron Lett., 44, 9205, (2003).

15. a) P. Lasszlo, Science, 235, 1473, (1987); b) B. Baghernejad, Lett. Org. Chem., 7, 255, (2010); c) S. Agarwal, J. N. Ganguli, J. Mol. Catal. A: Chem., 372, 44, (2013).

16. a) O. Marvi, M. Giahi, Bull. Korean Chem. Soc., 30, 2918, (2009); b) D. Habibi, O. Marvi, Catal. Commun., 8, 127, (2007); c) O. Marvi, M. Nikpasand, Lett. Org. Chem., 10, 353, (2013).

17. a) Determined in our laboratory by temperature-programmed desorption of ammonia gas ( $\left.\mathrm{NH}_{3}-\mathrm{TPD}\right)$ : P. Berteau, B. Delmon, Catal. Today, 5, 121 , (1989); b) Determined in our laboratory by the BET method: S. Brunauer, P. H. Emmett, E. Teller, J. Am. Chem. Soc., 60, 309, (1938).

18. a) R. Ballini, G. Bosica, R. Maggi, M. Ricciutelli, P. Righi, G. Sartori, R. Sartorio, Green Chemistry, 3, 178, (2001); b) G. Sartori, F. Bigi, R. Maggi, A. Mazzacani, G. Oppici, Eur. J. Org. Chem., 2513, (2001).

19. a) K. Kacprzak, Synth. Commun., 33, 1499, (2003). b) G. Hamprecht, J. Varwig, W. Rohr, US4680412 A, July 14, (1987).

20. a) R. A. W. N. Filho, M. A. T. Palm-Forster, R. N. de Oliveira, Synth Commun., 43, 1571, (2013); b) E. Benjamin, Y. Hijji, Molecules, 13, 157, (2008); c) Y. Peng, G. Song, X. Qian, Synth. Commun., 31(12), 1927, (2001). 